Semmelweis Egyetem, Fogorvostudományi Kar

Arc-, Állcsont-, Szájsebészeti és Fogászati Klinika

\title{
Az implantátumok méretváltozásának tendenciái az utóbbi években 1. rész
}

\author{
Rövid implantátumok szerepe a fogászati implantológiában. \\ Irodalmi áttekintés
}

DR. BÉRCZY KINGA, DR. LÁSZLÓ ZSUZSA, DR. GÖNDÖCS GYÖRGY, DR. SHKOLNIK TATIANA, DR. JOÓB-F. ÁRPÁD

\begin{abstract}
A csontintegráció feltételeit már évtizedekkel ezelőtt leírták, amelyek között szerepel a megfelelő méretű implantátum beültetése is. Ugyanakkor az utóbbi pár évben egyre többet lehet olvasni - mind a hazai, mind a külföldi irodalomban a rövid és a keskeny implantátumok szerepéről mint lehetőségről. Ezek az implantátumok alternatívái lehetnek a különböző csontpótlásoknak. Kiválthatják az időben hosszabb, költségesebb, beavatkozások számában magasabb horizontális és vertikális augmentációkat. Elkerülhetünk olyan komplikált, a beteg számára megerőltető és sok szövődményveszéllyel járó beavatkozásokat, mint a disztrakció vagy a nervus alveolaris inferior transzpozíció.

Célunk egy két részből álló irodalmi áttekintés annak érdekében, hogy képet kapjunk arról, valós alternatívát jelentenek-e a rövid és keskeny implantátumok.
\end{abstract}

Kulcsszó: rövid implantátum, vertikális csontpótlás, sikerességi ráta, túlélési ráta

Albrektsson és Brånemark [2] már a nyolcvanas évek elején leírták a megfelelő csontintegráció kialakulásának feltételeként - az implantátum anyaga, a megfelelő sebészi technika, a protetikai terhelés és a korszerü implantátum-felület kialakítás mellett - az implantátum megfelelő méretét. Korábban széles körben elfogadott szemlélet volt a rövid implantátumok alacsony sikerességi aránya és kiszámíthatatlan idejű túlélési aránya, valamint, hogy a csak standard hosszúságú implantátumok hozhatnak hosszú távú megbízható eredményeket. A rövid implantátumok alacsony sikerességi arányáról számos publikációban beszámoltak [13, 28]. Azonban az elmúlt időszakban egyre több beszámoló jelent meg a rövid implantátumok figyelemre méltó sikerességéröl. Kijelenthetjük, hogy ma a rövid implantátumok a fogászati implantológia klinikai vizsgálatainak reflektorfényébe kerültek. Jól példázza ezt, hogy a 2016 februárjában Kölnben megrendezett Európai Fogászati Implantológiai Társaság („European Association of Dental Implantologists", továbbiakban EDI) Konszenzus Konferenciájának egyik témáját is ez adta [8]. A rövid implantátumok használata számos előnnyel járhat. Alkalmazásukkal elkerülhetjük a vertikális csontpótlást, a felső állcsont poszterior régiójában megfelelő csontmagasság kialakítását célzó „sinus-lift” műtétet. Hatékonyabb az anatómiai képletek védelme, gyorsabbak és alacsonyabb morbiditásúak lesznek a beavatkozásaink és a költségek is jelentősen csökkennek, ösz- szehasonlítva az augmentációval kombinált implantációval.

Ugyanakkor számos kérdés merül fel használatukkal kapcsolatban. A kisebb felület miatt milyen lesz az implantátumok primér stabilitása, elegendő lesz-e a csontimplantátum-kapcsolat (,bone to implant contact”)? Milyen lesz a koronahossz-implantátumhossz-arány (,crown to implant ratio", továbbiakban $\mathrm{C} / \mathrm{I})$ ? Ezek együttesen mennyire befolyásolják az implantátum hosszú távú stabilitását? A rövidebb implantátumhossz nem okoz-e nagyobb vagy korai marginális csontveszteséget? Mi változott a korábbi eredményekhez képest, amiért egyre több sikerről számolnak be a rövid implantátumok használatával kapcsolatban? Munkánk során ezekre a kérdésekre kerestük a válaszokat az aktuális irodalomban.

A rövid implantátum fogalmának meghatározása folyamatosan változik [26]. Korábban az implantáció sikerességében komoly kockázati tényezőként szerepelt, ha az implantátum hossza az alsó állcsonton $<10 \mathrm{~mm}$, illetve a felső állcsonton < 13 mm [27]. A 2010 körül megjelent publikációkban még a $\leq 10 \mathrm{~mm}$ hosszúságú implantátumokat tekintették rövidnek [14]. A 2011ben megrendezett VI. EDI Konszenzus Konferencián $a \leq 9$ milliméteres implantátumokat fogadták el rövidnek. Az idei EDI Konszenzus Konferencián [8] ez az érték már csak $\leq 8 \mathrm{~mm}$, ugyanakkor meghatározták, hogy minimum 3,75 milliméteres átmérővel kell rendel- 
kezniük az implantátumoknak. Az ultra rövid implantátum mint új fogalom került meghatározásra, amelynek hossza $\leq 6 \mathrm{~mm}$.

Számos publikációban foglalkoznak azzal a kérdéskörrel, hogy milyen tulajdonságok megváltozása vezethetett ahhoz, hogy a Brånemark által megfogalmazott, a csontintegráció feltételeként leírt megfelelő implantátum-méret az idő előrehaladtával egyre kisebbé válik és számos sikerről beszámoló vizsgálat jelenik meg a témában.

Az egyik változás, hogy a korábbi implantátumok esztergált felszínnel rendelkeztek, így minimális volt a felületi érdesség, ez pedig alacsonyabb csont-implantátum („,bone-to-implant contact”) kapcsolatot jelentett [29]. Ennek eredményeként alacsony volt az ellenállásuk a tengelytől eltérő terhelésekkel szemben, ami a kortikális csont mikro-sérüléseihez, csontveszteséghez és a rövid implantátum sikertelenségéhez, elvesztéséhez vezetett [9]. A Sun és mtsai [21] által publikált „systematic review” eredményei alapján az esztergált felszínű rövid implantátumok $(6-8 \mathrm{~mm})$ sikertelensége 5,9-32,2\% közötti, míg a 10 mm hosszú implantátumoké $14,6 \%$. Felületkezelt implantátumok esetén ez az érték rövid implantátumoknál (6-8 mm) 0-3,6\%, míg 10 milliméteres implantátumoknál 0,5-4,7\%.

Egyértelmű következtetésként vonható le, hogy a felületkezelés kulcsfontosságú tényező a rövid implantátumok sikeressége szempontjából [5].

Számos munkacsoport vizsgálta a rövid implantátumok sikerességét az implantátum-átmérő változtatásának függvényében. Egyes elvek szerint nagyobb implantátum-átmérő esetén növekszik az implantátum összfelülete, a kortikális csontot alacsonyabb stresszhatás éri, csökkennek a csont mikro-sérülései. Egy vizsgálatban az esztergált felszínű < $5 \mathrm{~mm}$ átmérőjü rövid implantátumok (6-8 mm) sikertelenségi aránya 6,4\% volt. Ezzel ellentétben az $5 \mathrm{~mm}$ átmérőjü implantátumoké 20\% [10]. Más vizsgálatok ezt az elméletet nem erősítették meg [17, 23].

Az utóbbi évtizedben megváltozott a mútéti technika is. Az implantátumokat azok átmérőjéhez képest kisebb csontfészkekbe helyezzük, így nagyobb implantátumcsont-kapcsolat tud kialakulni [1].

A rövid implantátumok használatával megváltozik a korona-implantátum-arány, ennek korábban elfogadott maximális értéke 1 volt. Azonban kutatások kimutatták, hogy a megnövekedett korona-implantátum-arány nem jelent komoly rizikótényezőt mechanikai szempontból. Egy 10 éves prospektív vizsgálat TPS-sel felületkezelt implantátum esetén fordított arányosságot talált a $C / R$ és marginális csontveszteség között, azaz a nagyobb $\mathrm{C} / \mathrm{R}$ arány mellett alacsonyabb volt a marginális csontveszteség [4]. Garaicoa-Pazmiño és mtsai [6] 13 publikációt, összesen 2,072 darab 10 milliméternél rövidebb implantátumot értékeltek és hasonló eredményre jutottak.

Új implantátum-formák (pl.: „tapered”, „bone level”) és új implantátum-anyagok (TiZr-Roxolid), új felületkezelési technikák (SLActive) jelentek meg, amelyek hosszú távon szintén a rövid implantátumok sikerességének növekedéséhez vezethetnek [12]. Az új felszínek esetén, mint például az SLActive az osszeointegráció gyorsabban történik meg, az úgynevezett másodlagos stabilitás („secondary stability”) hamarabb alakul ki [11, 15]. A TiZr anyagból készült implantátumok jobb mechanikai tulajdonságokkal rendelkeznek, mint a tiszta titánimplantátumok [7]. Rövid implantátumok használatával, amennyiben azok „bone level” típusú implantátumok, nem feltétlenül csökken az implantátum felülete. Egy „tissue level” (Straumann) implantátum csavarmenetei között a távolság 1,25 milliméter. Egy „,bone level” (Straumann) esetén ez az érték 0,8 milliméter. Ez azt jelenti, hogy egy 4 milliméteres „bone level” implantátumon több csavarmenet helyezkedik el, mint egy 6 milliméteres „tissue level” implantátum esetén.

A rövid implantátumok sikerességéről számos publikáció jelent meg a közelmúltban.

Atieh és mtsai [3] irodalmi áttekintést végeztek a témában. Ennek során 1992 és 2011 között megjelent 33 publikáció (5 randomizált klinikai kutatás; 16 prospektív, nem randomizált, nem kontrollált kutatás; 12 retrospektív, nem randomizált kutatás; 1 prospektív és retrospektív adatokat is tartalmazott) anyagát dolgozták fel. Összesen 2,573 rövid implantátum ( $\leq 8,5 \mathrm{~mm}$ ) szerepelt a 33 beszámolóban. Egyéves utánkövetés során 59 sikertelen esetet írtak le, ezek 71\%-a még a protetikai megterhelés előtt történt. Összesen 101 implantátum esetén volt ötéves követés. Konklúzióként írták le, hogy a rövid implantátumok jó alternatívái lehetnek azoknak az eseteknek, amikor a hosszabb implantátumok behelyezéséhez csont augmentációra lenne szükség.

Srinivasan és mtsai [20] 12 publikáció (1987-2011) eredményeit dolgozták fel, melyekben összesen 690 db 6 mm-es Straumann implantátum szerepelt. Az utánkövetési idő 1 és 8 év között volt. Összesen 25 implantátum-vesztés történt, ezek 76\%-a a korai időszakban. A sikertelenség megoszlási aránya a maxillában $5,3 \%$, a mandibulában 1,4\%.

Rossi és mtsai [18] ötéves prospektív vizsgálatot végeztek. Ennek során 40 darab $6 \mathrm{~mm}$ hosszú, 4,1-4,8 mm átmérőjű, SLActive felszínű implantátumot helyeztek be moláris régiókba. Protetikai rehabilitáció mindegyik esetben szóló korona volt, megterhelés 6-7 héttel a mütétet követően történt. Két darab implantátumvesztés történt, mindkettő a protetikai megterhelés előtt. A marginális csontveszteség $0,7 \pm 0,6 \mathrm{~mm}$ volt.

Slotte és mtsai [19] 86 darab 4 milliméter hosszú implantátumot helyeztek el a mandibula hátsó régiójában. Az implantátumokat öt évig követték. Időközben összesen 6 implantátummal rendelkező két páciens elhunyt. Egy páciens az első évben három implantátumot vesztett. További öt implantátumvesztés történt (3-5 év között) három másik páciens esetén. Az implantátumokat rögzített fogpótlásokkal látták el. A túlélési arányuk 92,2\%. Az átlagos marginális csontveszteség 0,5 mm.

Telleman és mtsai [24] vizsgálataiból kiderült, hogy a $6 \mathrm{~mm}$ és a 9,5 mm hosszú implantátumok kétéves 
túlélési arányában nincs jelentős különbség. Az elöbbi $97,4 \%$-os, az utóbbi 98,6\%-os eredményt hozott, tehát a különbég $1,2 \%$. Azonban az $5 \mathrm{~mm}$ hosszú és a $6 \mathrm{~mm}$ hosszú implantátumok kétéves túlélési arányában jelentős különbség látható. Az $5 \mathrm{~mm}$-es implantátumok túlélési aránya $93,1 \%$, tehát a kettő közötti különbség 4,3\%. Továbbá konklúzióként vonták le, hogy a mandibulában elhelyezett rövid implantátumok prognózisa jobb, mint a maxillába helyezetteké.

A felső állcsonton manapság rutinszerüen alkalmazzuk a vertikális csontmagasságot növelő különböző sinus elevációs mütéteket. Nyitott „sinus-lift” esetén a sikerességi arány 98,3\% [16], zárt sinus-lift esetén 92,8\% [22]. Ehhez képest vajon mennyi a rövid implantátumok sikerességi aránya? Thoma és mtsai [25] arra a kérdésre keresték a választ, hogy a maxilla hátsó régiójában „sinus-lift'-et követően hosszú implantátummal, vagy augmentáció nélkül, rövid implantátum használatával érhető-e el jobb eredmény. Nyolc randomizált kontrollvizsgálat eredményét összegezték. 197 darab rövid ( $\leq 8 \mathrm{~mm}$ ) implantátum (augmentáció nélkül) és 209 darab hosszú ( $\geq 8 \mathrm{~mm}$ ) implantátum (augmentációt követően) behelyezés történt. A követési idő az implantációt követően 8-18 hónap, a túlélési arány ezen idő alatt $97-100 \%$. A nyolc publikációból csak három vizsgálta a túlélési időt 12 hónappal a protetikai megterhelés után, ezek eredménye alapján mindkét mütéti technikánál $100 \%$-os volt a túlélési arány. Biológiai komplikáció rövid méretű implantátum estén 8 esetben fordult elő ( 5 intra-, 3 posztoperatív). A csontaugmentált betegeknél 21 biológiai komplikáció fordult elő (ebből 16 a sinus-elevációval összefüggésben, pl. sinus membrán perforáció). A publikációk alapján a marginális csontveszteség rövid implantátumoknál 0,1 és 1,02 mm között mozgott. Hosszú implantátumok esetén 0,1 és $1,15 \mathrm{~mm}$ közötti értékek szerepeltek. A páciensek a kevésbé invazív, rövid implantátumok használatát preferálták jobban, bár a szerzők szerint a páciensek elégedettsége nem standardizált és nem összehasonlítható módszerekkel történt. A mütéti idő és a várható költségek tekintetében egyértelmüen a rövid implantátumok használata mutatott kedvezőbb eredményt. A rövid implantátumok behelyezési ideje 15 és 165 perc között mozgott, míg a csontaugmentációs mútétek 20 és 210 perc idót vettek igénybe. A rövid implantátumok átlagos mútéti költsége 941 euró volt, míg az augmentáció és a hosszú implantátum együttes költsége átlagban 1.944 euró volt. A szerzők szerint annak ellenére, hogy az eredmények alapján mindkét módszer biztonsággal és kiszámíthatóan használható, az eredményeket óvatosan szükséges kezelni, föleg a rövid implantátumok behelyezése utáni követési idő miatt. Felhívják a figyelmet arra, hogy a vizsgálatok a túlélési időről, a marginális csontveszteségröl, valamint a biológiai komplikációról pontosan, viszont a protetikai sikerességről következetlenül számolnak be, vagy nincs róluk adat. Szükségesnek tartják továbbá hosszú távú prospektív vizsgálatok elvégzését.

A már korábban említett, idén megrendezett kölni
EDI Konszenzus Konferencián megfogalmazásra kerültek a rövid implantátumok indikációi, illetve a komplikációk megelőzésének feltételei [8].

Indikációként tekintik mind a felső, mind az alsó állcsont részleges foghiányait a moláris régióban, amenynyiben az anatómiai képletek (sinus maxillaris, nervus alveolaris inferior) közelsége miatt nem elégséges a vertikális csontmagasság standard méretú implantátum behelyezéséhez, de a horizontális csontvolumen elegendő $\geq 3,75 \mathrm{~mm}$ átmérőjü implantátum alkalmazásához. Szintén indikációs terület a részleges kivehető fogpótlások elhorgonyzásához frontális régióba végzett implantáció.

A komplikációk elkerülése érdekében nem javasolják az esztergált felszínű implantátumok használatát. A rövid implantátumok alkalmazását csak megfelelő csontminőség esetén ajánlják. Kerülendő az implantátumokat oldal irányú erőbehatásoknak kitenni, tehát csak megfelelő okklúzió esetén használhatók a rövid implantátumok. Javasolják a „bone level” és a „tapered” típusú implantátumok használatát. Fontos mind a sebész, mind a protetikus megfelelő szakmai gyakorlata. Ugyanakkor nem foglalnak állást a rövid implantátumok azonnali megterheléséröl, mivel a témában nem áll rendelkezésre megfelelő mennyiségű információ.

\section{Összefoglalás}

Az említett irodalmi adatok alapján a rövid implantátumok használata kiszámítható és biztonságos módszernek tünik, valós alternatívája lehet a csontaugmentációs mútéteknek. Azonban a kapott eredményeket óvatosan kell kezelnünk. Nem beszélhetünk „evidence based”röl. Ennek egyik oka a publikációk többségében szereplő rövid követési idő. Gyakori probléma a protetikai megterhelést követő, hosszú távú sikeresség-arány hiánya. A szerzők tudják, hogy irodalmi áttekintésük közel sem teljes. Célkitüzésükként sem ez szerepelt. A maguknak feltett kérdésekre (csont-implantátum-felület?, marginális csontveszteség?, korona-implantátumarány?, túlélési arány?) az angol nyelvú irodalomban keresték a választ. A téma iránt kimagasló nemzetközi érdeklódés mutatkozik. Erre való tekintettel retrospektív vizsgálatot indítottunk klinikánk anyagából. A behelyezett rövid, valamint keskeny implantátumok adatait a páciensek aktuális kontrollvizsgálatai során rögzítjük. Reményeink szerint hosszú távú, megbízható és szignifikáns eredményeket kapunk, melyeket hamarosan publikálni tudunk.

A jelenlegi nemzetközi trendekböl - a rövid és keskeny implantátumok alkalmazásával kapcsolatban - is kiderül, hogy a fogászati implantológiában még az alaptudományhoz tartozó, csontintegrációt befolyásoló tényezők, vizsgálatok is milyen fontosak. Hajlamosak vagyunk mindig az újat keresni, új mútéti technikákat, új eszközöket kutatni, fejleszteni, és a több évtizede felfe- 
dezett és leírt tényeket evidenciának kezelni. Pedig az új anyagok (pl. TiZr), új implantátumfelszínek vizsgálata, vagy akár az implantátum méretének a változtatása is hozhat új eredményeket.

Későbbiekben terveink között szerepel a keskeny implantátumok aktuális irodalmi összefoglalójának elkészítése.

\section{Irodalom}

1. Al-Marshood MM, Junker $R$, Al-Rasheed $A$, Al Farraj Aldosari $A$, JANSEN JA, ANIL S: Study of the osseointegration of dental implants placed with an adapted surgical technique. Clin Oral Implants Res. 2011; 22: 753-759.

2. Albrektsson T, Brånemark PI, Hansson HA, Lindström J: Osseointegrated titanium implants. Acta orthop. scand. 1981; 52: 155-170.

3. Atieh MA, Zadeh H, Stanford CM, Cooper LF: Survival of short dental implants for treatment of posterior partial edentulism: a systematic review. J Oral Maxillofac Implants. 2012; 27: 1323-1331.

4. Blanes R, Bernard J, Blanes Z, Belser U: A 10-year prospective study of ITI dental implants placed in the posterior region. II. Influence of the crown-to-implant ratio and different prosthetic treatment modalities on crestal bone loss. Clin Oral Implants Res. 2007; 18: 707-714.

5. DiPORTER D: Short dental implants: what works and what doesn't? A literature interpretation. Int J Periodontics Restorative Dent. 2013; 33: 457-464.

6. Garaicoa-Pazmiño C, Suarez F, Monje A, Catena A, Ortega-Oller I, Galindo-Moreno P, WANG HL: Influence of Crown-Implant Ratio Upon Marginal Bone Loss. A Systematic Review. J Periodontol. 2014; 85: 1214-1221.

7. Gottlow J, Dard M, KJellson F, Obrecht M, Sennerby L: Evaluation of a new titanium-zirconium dental implant: a biomechanical and histological comparative study in the mini pig. Clin Implant Dent Relat Res. 2012; 14: 538-545.

8. Guidines of the 11th European Consensus Conference. Short, angulated and diameter-reduced implants. EDI Journal. 2016; 12: $16-19$.

9. Hagi D, Deporter D, Pilliar R, Arenovich T: A targeted review of study outcomes with short $(<7 \mathrm{~mm})$ endosseous dental implants in partially edentulous patients. J Periodontol. 2004; 75 : 798-804.

10. Ivanoff C, Grondahl K, Sennerby L, Bergstrom C, Lekholm U: Influence of variations in implant diameters: A 3-to5-year retrospective clinical report. Int J Oral Maxillofac Implants. 1999; 14: 173-180.

11. Lang NP, Salvi Ge, Huynh-Ba G, Ivanovski S, Donos N, BossHARDT DD: Early osseointegration to hydrophilic and hydrophobic implant surfaces in humans. Clin Oral Implants Res. 2011; 22: 349-356.

12. Lombardo G, Corrocher G, Pighi J, Faccioni F, Rovera A, MaRINCOLA M, et al: The impact of subcrestal placement on short locking-taper implants placed in posterior maxilla and mandible: a retrospective evaluation on hard and soft tissues stability after 2 years of loading. Minerva Stomatol. 2014; 63: 391-402.

13. Naert I, Kautsikakis G, Duyck I: Biologic outcome of implant-supported restorations in the treatment of partial edentulism. Part I. A longitudinal clinic evaluation. Clin Oral Implants Res. 2002; 13: 381-389.
14. Nkenke E, Stelzze F: Clinical outcomes of sinus floor augmentation for implant placement using autogenous bone or bone substitutes: a systematic review. Clin Oral Implant Res. 2009; 4: 124-133.

15. Oates TW, Valderrama $P$, Bischof M, Nedir R, Jones A, Simpson J, Toutenburg $H$, Cochran DL: Enhanced implant stability with a chemically modified SLA surface: a randomized pilot study. Int J Oral Maxillofac Implants. 2007; 22: 755-760.

16. PJetursson BE, Tan WC, Zwalen M, Lang NP: A systematic review of the success of sinus floor elevation end survival of implants inserted in combination with sinus floor elevation. Part 1: Lateral approach. J Periodontol. 2008; 35: 216-240.

17. Pommer B, Frantal S, Willer J, Posch M, Watzek G, Tepper G Impact of dental implant lenght on early failure rates: A metaanalysis of observational stidies. J Periodontol. 2011; 38: 856863.

18. Rossi F, Lang NP, Ricci E, Ferraiol L, Marchetti C, Botticell D: Early loading of 6-mm-short implants with a moderately rough surface supporting single crowns - a prospective 5-year cohort study. Clin Oral Implants Res. 2015; 26: 471-477.

19. Slotte C, Grønningsaeter A, Halmøy AM, Ohrnell lO, MordenFELD A, ISAKSSON S, Johansson LA: Four-Millimeter-Long Posterior-Mandible Implants: 5-Year Outcomes of a Prospective Multicenter Study. Clin Implant Res. 2015; 17: 385-395.

20. Srinivasan M, Vazquez L, Rieder P, Moraguez O, Bernard JP, BelSER UC: Survival rates of short $(6 \mathrm{~mm})$ micro-rough surface implants: a review of literature and meta-analysis. Clin Oral Implants Res. 2014; 25: 539-545.

21. Sun HL, Huang C, Wu YR, SHI B: Failure rates of short $(<10)$ dental implants and factors influencing theur failure: A systematic review. Int J Oral Maxillofac Implants. 2011; 26: 816-825.

22. Tan WC, Lang NP, Zwahlen M, PJetursson BE: A systematic review of the success of sinus floor elevation end survival of implants inserted in combination with sinus floor elevation. Part 2: Transalveolar technique. J Periodontol. 2008; 35: 241-254.

23. TAWIL G, YounAn R: Clinical evaluation of short, machine-surface implants followed for 12 to 92 months. Int J Oral Maxillofac Implants. 2003; 18: 894-901.

24. Telleman G, Raghoebar GM, Vissink A, den Hartog L, Huddleston Slater JJ, MeiJer HJ: A systematic review of the prognosis of short $(<10 \mathrm{~mm}$ ) dental implants placed in partially edentulous patient retrospective study of 5-10 years. J Periodontol. 2011; 38: 667-676.

25. Thoma DS, Zeltner M, Hüsler J, Hämmerle CH, Jung RE: Short implants versus sinus lifting with longer implants to restore the posterior maxilla: a systematic review. Clin Oral Implants Res. 2015; 26: 154-169.

26. VAJdOVICH I, Orosz M: A short implantátumok alkalmazásának tapasztalatai az irodalomban. Fogorvosi Szemle. 2015; 2: 39-43.

27. van Steenberghe D, Lekholm U, Bolender C, Folmer T, Henry P, Herrmann I, et al: The applicability of osseointegrated oral implants i the rehabilitation op partial edentulism: A prospective multicenter study of 558 fixtures. Int J Oral Maxillofac Implants. 1990; 5: 272-281.

28. Weng D, Jacobson $Z$, Tarnow D, Hureler MB, Faehen O, Sanavi $F$, et al: Multicenter prospective clinical trial of $3 i$ machined surface implants: result after 6 year of follow-up. Int J Oral Maxillofac Implants. 2003; 18: 417-423.

29. Wennerberg A, Ektessabi A, Albrektsson T, Johansson $C$, Anderson B: A 1-year follow-up of implants of differing surface roughness placed in rabbit bone. Int J Oral Maxillofac Implants. 1997; 12: 486-494. 
BÉRCZY K, LÁszló Zs, Göndöcs Gy, SHKOLNIK T, JoóB-F Á

Changes of trends in the size of the dental implants in recent years

Part 1.

The role of short implants in dental implantology

The literature review

The requirements for osseointegration have been determined decades ago, among which was the appropriate size of the dental implants. In the last few years, in both - domestic and foreign literature- we can find more and more articles suggesting short and narrow dental implants as a treatment possibility. They may serve as an alternative to various bone grafting techniques and may replace the time demanding, more invasive and expensive horizontal and vertical bone augmentation procedures. Using short and narrow implants we can avoid interventions often accompanied by serious complications, such as bone distraction and inferior alveolar nerve transposition which pose greater risk for the patient. Our objective is a two-part review of the periodic literature in order to establish whether short and narrow dental implants can serve as a real alternative treatment modality.

Key words: short implant, vertical bone augmentation, succes rate, survival rate

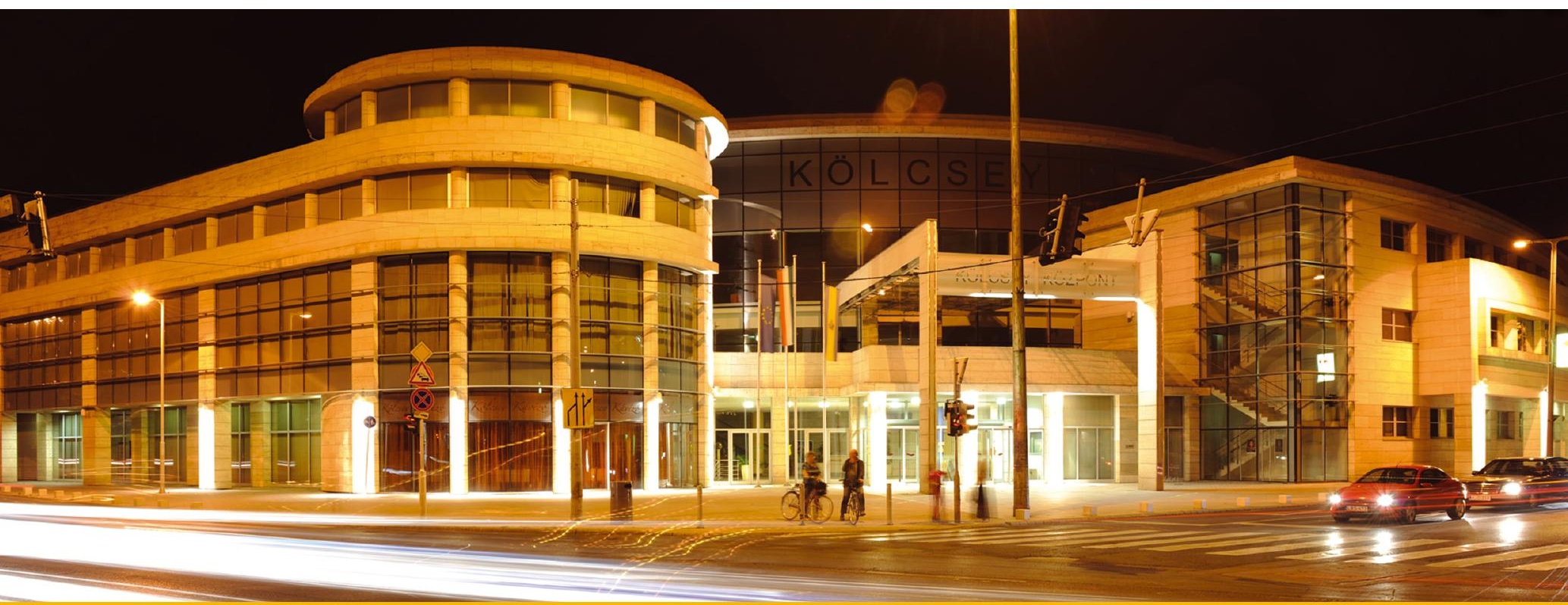

Helyszín: Debrecen, Kölcsey Konferencia Központ (Hunyadi u. 1-3.)
2017.
október $5-1$
$5-7$.
MAiszi

XXI. Magyar Arc-Állcsont és Szájsebészeti Kongresszus

XI. Danubius Nemzetközi Kongresszus

Magyar Fogorvosok Egyesülete Fogpótlástani Társaságának XXII. kongresszusa és továbbképzó tanfolyamai 